\title{
An alternative methodology for teaching and evaluation in medical education: crosswords
}

\author{
VASCONCELOS, A. C. C. G., SOARES, M. C., SILVA, F. R. P. and \\ VASCONCELOS, D. F. P.*

\begin{abstract}
Universidade Federal do Piaui - UFPI, Av. São Sebastião, 2819, Reis Veloso, CEP 64204-035, Parnaíba, PI, Brasil
\end{abstract} \\ *E-mail: vasconcelos@ufpi.edu.br
}

\begin{abstract}
Introduction: Crosswords have been used to complement medical education in a fun way, yet they were not used as a method for the evaluation of students' performance. Objective: The aim of this study was to describe the development of crosswords and verify their validity as a method of performance evaluation in embryology. Materials and Methods: We used crossword based on subjects about stages of embryonic development with different levels of difficulty. To validate the crossword as the evaluation method of teaching, two evaluation methods were applied (the traditional and with crosswords, simultaneously) on students of Federal University of Piaui. The performance of students was analyzed with Pearson's correlation coefficient and data were analyzed to check for normal distribution through the Shapiro-Wilk test with significance level of 0.05 . The tests were performed on the BioEstat statistical software version 5.0. Results: As result a total of 28 students were evaluated. It was observed that the resulting score of both the traditional and crossword evaluation methods demonstrating normal distribution $(p=0.4127$ and $p=0.7016$, respectively), did not present vices and tendencies. The average scores were $7.1 \pm 2.0$ and $6.9 \pm 1.7$ for the traditional and crossword evaluation methods, respectively, showing statistically significant difference $(p=0.0001 ; \mathrm{r}=0.67)$, demonstrating a moderate Pearson's correlation between the methods. Conclusion: In conclusion, crosswords may be used as supplementary material for teaching embryology. Also, crossword functioned as validated and reproducible method of performance evaluation that can be used in as alternative and/or complementary teaching of embryology or other disciplines in the medical field.
\end{abstract}

Keywords: testing, basic science education, quantitative research methods.

\section{Introduction}

Many efforts have been made in the medical field to render the most effective teaching-learning process. For this purpose, several methodologies have been and continue to be used as: board game (ROSE, 2011), cards games (ROSADAS, 2012), information and technology communication (BUTTON, HARRINGTON and BELAN, 2013; KOIVUNEN, ANTTILA, KUOSMANEN et al., 2014; VASCONCELOS and VASCONCELOS, 2013), using the internet (ALFIERI, PORTELANCE, SOUHAMI et al., 2012), the use of social networks (FORGIE, DUFF and ROSS, 2013; MCANDREW and JOHNSTON, 2012; TAM and EASTWOOD, 2012), teaching video (KNÖSEL, JUNG and BLECKMANN, 2011), as well as the crosswords (BAILEY, HSU and DICARLO, 1999; CALDERON, SACHDEVA, ROY-CHAUDHURY et al., 2012; GAIKWAD and TANKHIWALE, 2012; RAINES, 2007; SAXENA et al., 2009; SHAH, LYNCH and MACIAS-MORIARITY, 2010; SPEERS, 1994).

The crossword appeared around the thirteenth century before Christ more advanced than the current configuration. In 1913, the first crossword puzzle was published in a newspaper, in New York, in a section called "Fun" (English - funny, fun, joke). Since then, the crossword has appeared in newspapers and magazines as a way to pass time, and as fun and entertainment. Nevertheless, these characteristics are contributing in different areas of medical education (RAINES, 2007).
A study showed that $88.1 \%$ of medical students reported the crosswords to be a useful tool for teaching, and $93.5 \%$ of students were favorable to its continued use as a supplementary tool in teaching patology (SAXENA et al., 2009).

In pharmacology, the crosswords were also used to assist teaching on antiulcer agents, being considered as promoters of self-learning (GAIKWAD and TANKHIWALE, 2012). Teaching of caring for critically ill patients in nursing also employed this methodology as an alternative (SPEERS, 1994).

In physiology, the crossword assisted in teaching about the urinary system (CALDERON, SACHDEVA, ROY-CHAUDHURY et al., 2012) and the gastrointestinal tract, with positive results in the teaching-learning process, revealing to students the important for the sedimentation of knowledge in a fun way (BAILEY, HSU and DICARLO, 1999).

In embryology, several methodologies have been employed in order to facilitate the process of teaching and learning. A 2013 study showed that when the subjects of embryology were correlated with clinical findings in recent years, college students became more active (SCOTT, CHARLES and HOLLAND, 2013). Another study used for teaching on-line classes on embryology at an American university described crosswords as a new methodological approach in the area (NIEDER and BORGES, 2012).

In Brazil, medical students in a private university in São Paulo had the support of embryological models at different stages of 
human development in the discipline of embryology. The study revealed that this method encouraged the self-learning in an active way (OLIVEIRA, KERBAUY, FERREIRA et al., 2012).

The benefit that crosswords can bring to the teaching-learning process is remarkable (BAILEY, HSU and DICARLO, 1999; CALDERON, SACHDEVA, ROY-CHAUDHURY et al., 2012; GAIKWAD and TANKHIWALE, 2012; RAINES, 2007; SAXENA et al., 2009; SHAH, LYNCH and MACIAS-MORIARITY, 2010; SPEERS, 1994), but none of these works investigated the possibility for crosswords to function as a method for the evaluation of students' performance, since the evaluation in higher education is essential for a diagnosis of university performance and the level of knowledge of the health professional future.

Traditionally, the evaluation, most of the time, sets up a negative aspect, where on one side appears the teacher, and on the other side appears the student learning things by heart. For the student, the only way is to be approved by the good performance in the ratings. Thus, the assessment may interfere with the educational learning process (BURIASCO, 2000; DAVIS, PONNAMPERUMA and KER, 2009).

The objective of this study was to describe the development of crosswords as supplementary teaching material and its use as a valid tool for the evaluating of students' performance in the discipline of embryology alternative method.

\section{Materials and Methods}

\subsection{Ethics principles}

This experience report obeyed all current resolutions and it was approved by the Ethical Committee in Research of Federal University of Piaui (CAAE: 07666212.3.0000.5214), also followed the code of Ethics of the World Medical Association (Declaration of Helsinki).

\subsection{Development of the crossword on embryology}

The crossword created subjects that are basic for the teaching courses in the area of health. Evolved crosswords divided according to the syllabus of the discipline of embryology, as follows: $1^{\text {st }}$ Week of Human Development (WHD); $2^{\text {nd }}$ WHD, $3^{\text {rd }}$ WHD, $4^{\text {th }}$ to $8^{\text {th }}$ WHD; fetal period; placenta and embryonic annexes. Crosswords were developed based on scientific articles in reputable books on embryology, in two different ways: with a specific program for this purpose, and without the aid of this program.

The development of the Crossword Eclipse Crossword ${ }^{\mathrm{TM}}$ (ECLIPSECROSSWORD, 2015) used the program. As the "answer" was inserted, there was already a specific field to place the tip, and who did the crossing of crosswords was the program itself automatically.

The other form of development of Crossword was without the aid of this program. Crosswords were built with the help of Microsoft Office Excel ${ }^{\mathrm{TM}}$ - the 2007 version, in a worksheet in which $300-400$ cells were selected $(20 x 15-20), 20$ vertically and horizontally 15 to 20 . All intersections of words were visually created (Figure 1), allowing a crossword with different levels of difficulty: easy, medium and hard.

\subsection{Crossword difficulty}

For the graduation of the difficulty, we used some techniques that were arranged in crossword tips as prior knowledge, word association, structural and specific letters. Prior Knowledge

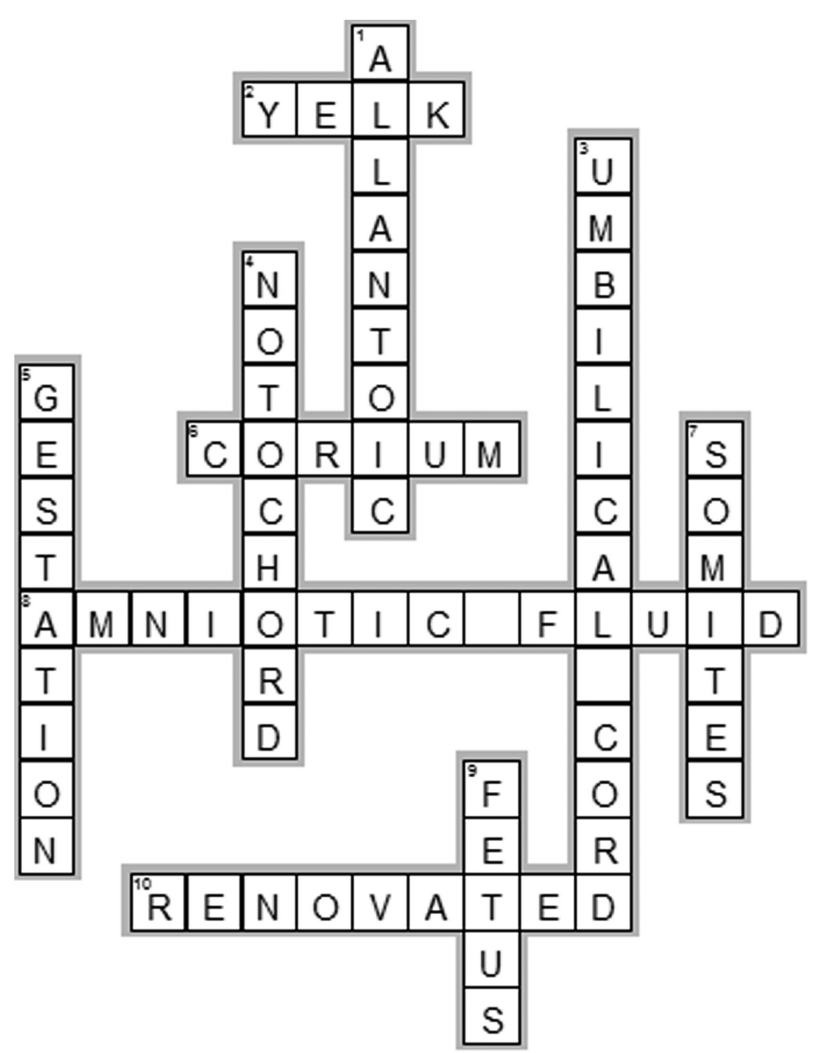

Figure 1. Crosswords developed for the evaluation of students' performance.

refers to all knowledge previously acquired over a subject matter or simply through a brief contact with it. The tips were used as a means of inducing the response precisely or with a lower precision (Table 1). The word association can use the tips with contradictory words or terms, or tips that make up the association by similarity and by derivation of words with prefixes or suffixes (Table 1). Another method used to moderate the level of difficulty of crosswords was the structural technique, in which the very word with its cell number (letters of each answer) contributed to the discovery of the correct word from the sentence (Table 1). Moreover, the specific letters helped in controlling the difficulty, because as responses were discovered and completed in the crossword, it became easier to know what are the crossword (letters) that would miss being completed. Thus, to make the most difficult crosswords, it was necessary to maintain such a word with fewer intersections with it, decreasing the chances of fulfillment by knowing the answer of another clue (NICKERSON, 2011; SKOTKO, KENSINGER, LOCASCIO et al., 2004).

For example, in Figure 1, the tip for 6 sentence is "structure that develops in the second week of human embrionary development; in the future, it will give rise to part of the placenta and its early development is formed by: syncytiotrophoblast, cytotrophoblast and extra-embrionary mesoderm" and the answer that properly completed it was "corium", which showed two intersections with the tips: which were "notochord" (4) and allantoic ( 1 ) positioned on the vertical lines. 
Table 1. Example of ways to scale the difficulty crossword.

\begin{tabular}{lcc}
\hline & Induce an answer specifically & Answer \\
Fore knowledge & Male gamete & Spermatozoon \\
& Organ where the fetus develops & Uterus \\
& Induce the answer with less precision & Answer \\
& Fusion of espermatozoon with oocyte II & Zygote \\
& Repeated mitotic divisions of the blastomeres & Answer \\
& Contrast tips & Ovary \\
& Testicles & Vagina \\
Crossword association & Penis & Answer \\
& Similarity tips & Testicles \\
& Scrotal sac & Endometrium \\
Structural & Uterus & Answer \\
Specific letters & Tips with derivation of words & Spermatozoon \\
\hline
\end{tabular}

Table 2. Data for the two ways of evaluation.

\begin{tabular}{lcc}
\hline & \multicolumn{2}{c}{ Evaluation methods } \\
\cline { 2 - 3 } & Traditional & Crossword \\
\hline Students & 28 & 28 \\
Grades (mean) & 7.1 & 6.9 \\
Standard deviation & 2.0 & 1.7 \\
Median & 7.1 & 7.0 \\
Pearson's correlation & $\mathrm{r}=0.67(p=0.0001)$ \\
\hline
\end{tabular}

\subsection{Crossword as supplementary material for teaching embryology}

The developed material featured 150 crosswords in three difficulty levels. Students used the crossword as a supplementary activity in laboratory embryology classes.

Application of crosswords as an alternative method for assessing the performance

Crosswords were not previously held, in any way, by the students who were assessed, so that there was influence of the learning correlation with the methodology, with an unprecedented form of assessment for these students. This study evaluated the crossword, developed without the use of Eclipse Crossword ${ }^{\mathrm{TM}}$ program, for students in the $2^{\text {nd }}$ semester of 2013 in a biomedicine school Federal University, during a normal theoretical evaluation of the semester. Crosswords that addressed the broad and basic course contents provided to the discipline mode were created. Crosswords were then applied as a theoretical review of embryology individually. This evaluation was performed by 28 students enrolled, who answered the two assessments (traditional and with crosswords) simultaneously (within a time period of 120 minutes). Traditional assessment contained 22 questions, worth 10 points, with 18 to judge whether the sentence was true or false (value of 0.33 point for each correct sentence), a descriptive question (worth 2 points) and two multiple-choice questions with five alternatives (worth 1 point each), based on studies that found the forms most commonly used in the evaluation of higher teaching (OLIVEIRA and SANTOS, 2005).

\subsection{Correction of ratings}

Evaluation with the crossword presented 10 sentences arranged in columns (vertical) and rows (horizontal) (Figure 1), in which each sentence completely and correctly filled was worth one point. For the traditional evaluation, we compared the responses with the contents of books with respected texts, papers and lectures on embryology.

\subsection{Statistical analysis}

Data were analyzed to check for normal distribution through the Shapiro-Wilk test. To compare the academic performance of students according to the evaluation method, Pearson's correlation coefficient was used. For both tests, a significance level of 0.05 was considered. The tests were performed on the BioEstat software version 5.0 (Belém, PA, Brazil).

\section{Results}

150 crosswords were developed and classified into 3 levels of difficulty: easy, medium and hard. Crossword topics addressed the issues commonly belonging to any discipline plan of Embryology in the medical field, such as: $1^{\text {st }}$ WHD, $2^{\text {nd }} \mathrm{WHD}, 3^{\text {rd }} \mathrm{WHD}, 4^{\text {th }}$ to $8^{\text {th }} \mathrm{WHD}$, fetal period and embryonic annexes, in which each topic presented words crossed as easy, medium and hard.

When comparing the two forms of assessment, data showed that in both the traditional method and the method that used the crossword, the grades had a normal distribution $(p=0.4127$ and $p=0.7016$, and the traditional crosswords respectively) as is showed in Figure 1.

The mean scores were 7.1 and 6.9 for the methods: traditional and crosswords respectively, with statistically significant difference $(p=0.0001 ; \mathrm{r}=0.67)$, demonstrating a correlation positive and strong; the standard deviation and median can be seen in Table 2 .

\section{Discussion}

This study describes the development of a series of crosswords, which were used in embryology practical classes, as a way to make learning more interesting, fun and productive for the 
student of embryology, corroborating with other studies (BAILEY, HSU and DICARLO, 1999; CALDERON, SACHDEVA, ROY-CHAUDHURY et al., 2012; GAIKWAD and TANKHIWALE, 2012; RAINES, 2007; SPEERS, 1994).

A traditional method and one which used the crossword: Two evaluations were applied. The traditional mode of assessment applied to students is also being used in other institutions of higher education. A private university in São Paulo showed that the most commonly used forms of assessment was essay tests $(32.9 \%)$, followed by tests with multiple choices $(10.6 \%)$, both performed individually (OLIVEIRA and SANTOS, 2005).

Another study conducted in Portugal showed that multiplechoice tests were used in $70.8 \%$ of the methodology (PEREIRA and FLORES, 2012), standards followed by our study for the development of traditional evaluation.

Regarding the development of the crossword, use of the EclipseCrossword ${ }^{\mathrm{TM}}$ program allowed the creation of crosswords in an easier and quicker way. This is due to the features presented by the program, which can save the crossword developed in different file formats (Rich Text Format - RTF, Windows metafiles - WMF, PostScript - EPS, Across Lite Text Format - allowing the export of crosswords to other editors of crosswords Interactive with JavaScript and Java applet - which enable the use of crosswords on a website on the internet). Another feature was the possibility of creating different types of crosswords with the same tips, but arranged differently, with a simple mouse click.

Concerning the development of crosswords without the aid of Eclipse Crossword ${ }^{\mathrm{TM}}$ program, the work became more manual and slow, since every crossing between words was carried out in a visual and orderly manner. That allowed a possibility that was limited when using the program Eclipse Crossword ${ }^{\mathrm{TM}}$ : the greater control over the level of difficulty of crosswords created. By using the Eclipse Crossword ${ }^{\mathrm{TM}}$ program, it automatically made the crossing between words, making it impossible to construct crossword based on techniques: structural and specific letters, as illustrated in Table 1 . Decreasing the possibility of adjusting the difficulty level of the crossword created.

Crossword puzzles have been developed in both ways and were applied to students of embryology as an alternative assessment developed without the use of Eclipse Crossword ${ }^{\mathrm{TM}}$ program given to create crosswords with greater possibilities in adjusting the degree of difficulty.

In literature, there is the report of a patient with amnesia who solved 277 crosswords; by analyzing such crosswords solved, the researchers found that patients had a greater number of errors (54\%) to complete the crossword puzzle that had hints horizontally, compared with those displayed vertically $(45 \%)$. However, researchers justify that difference may only be a matter of personal preference on how to solve the puzzle, since the patient studied solved the tips arranged in horizontal lines before the vertical lines (SKOTKO, RUBIN and TUPLER, 2008).

Another study showed that even the crossword is not developed symmetrically, ie., equal number of tips arranged in vertical and horizontal lines, the crossword functioned quite complementary and in a fun way (CALDERON, SACHDEVA, ROY-CHAUDHURY et al., 2012).

In crosswords applied to students of embryology as a method of assessment, care was taken to prepare the crossword so that they were distributed in equal number of tips positioned in horizontal lines and vertical lines, although a study have shown that the positioning of the tips in the vertical and horizontal lines did not present statistically significant difference compared to the solution (HAMBRICK, SALTHOUSE and MEINZ, 1999).

Possibly such care during the development of crosswords contributed so that in both reviews the notes were distributed as normal (Figure 1). That represented that such methods of evaluation were not addicted and did not show trends.

Why use the crossword as an evaluation method in embryology? Crosswords tested as an alternative assessment tool showed a strong Pearson's correlation $(p=0.0001 ; r=0.67)$ between different methods from the academic performance evaluation that was performed in the traditional way, suggesting a possible replacement and / or supplement of the assessment methods commonly used.

For the student, the only way to obtain the approval is through the assessment; the assessment may become an influencing factor in learning.

What may limit the depth in other related matters, since the student will study only the content that will be asked (OLIVEIRA and SANTOS, 2005)? Students end up devoting themselves to decorate content just to make good grades, resulting in a short-lived memory. Note, this case does not represent the actual knowledge of the student and gets a negative review with the teacher charging on one hand, and students learning by heart on the other (BURIASCO, 2000). Crosswords used could minimize this negative aspect, since they are recognized as a recreational activity (BAILEY, HSU and DICARLO, 1999; CALDERON, SACHDEVA, ROY-CHAUDHURY et al., 2012; GAIKWAD and TANKHIWALE, 2012; RAINES, 2007; SPEERS, 1994), even if applied in groups rather than individually.

What could enable the evaluation process to become more tranquil (KARIMBUX, 2013), interfering positively in the teaching-learning process? Not only in the discipline of embryology, as well as in other disciplines in medical education, to enable this evaluation method, the crossword.

\section{Conclusion}

Crosswords proved to be a developed method for the alternative and/or complementary validated and reproducible method for the verification of academic performance assessment when compared with the traditional method of assessment in the discipline of embryology.

Acknowledgements: Research supported by the Federal University of Piaui (UFPI - Edital PIBIC 2013/2014 and BIAMA 03/2014). We thank teacher Abilio Borghi for the grammar review of the manuscript.

\section{References}

ALFIERI, J., PORTELANCE, L., SOUHAMI, L., STEINERT, Y., MCLEOD, P., GALLANT, F. and ARTHO, G. Development and impact evaluation of an e-learning radiation oncology module. International Journal of Radiation Oncology, Biology, Physics, 2012, vol. 82, n. 3, p. e573-e580. http://dx.doi.org/10.1016/j.ijrobp.2011.07.002. PMid:22024203.

BAILEY, CM., HSU, CT. and DICARLO, SE. Educational puzzles for understanding gastrointestinal physiology. The American Journal of Physiology, 1999, vol. 276, n. 6 Pt 2, p. S1-S18. PMid:16211663. 
BURIASCO, RLC. Algumas considerações sobre avaliação educacional. Avaliação Educacional, 2000, vol. 22, p. 155-178.

BUTTON, D., HARRINGTON, A. and BELAN, I. E-learning \&amp; information communication technology (ICT) in nursing education: A review of the literature. Nurse Education Today, 2013, vol. 13, p. 162-165. PMid:23786869.

CALDERON, KN., SACHDEVA, MB., ROY-CHAUDHURY, PT. and JHAVERI, KD. Nephrology Crossword: Interventional nephrology--dialysis access and beyond! Kidney International, 2012, vol. 81, n. 3, p. 327-328. http://dx.doi.org/10.1038/ki.2011.373. PMid:22241567.

DAVIS, MH., PONNAMPERUMA, GG. and KER, JS. Student perceptions of a portfolio assessment process. Medical Education, 2009, vol. 43, n. 1, p. 89-98. http://dx.doi.org/10.1111/j.13652923.2008.03250.x. PMid:19141002.

ECLIPSECROSSWORD. Available from: <hhttp://www.eclipsecrossword. com>. Access in: 8 Jan. 2015.

FORGIE, SE., DUFF, JP. and ROSS, S. Twelve tips for using Twitter as a learning tool in medical education. Medical Teacher, 2013, vol. 35, n. 1, p. 8-14. http://dx.doi.org/10.3109/0142159X.2012.746448. PMid:23259608.

GAIKWAD, N. and TANKHIWALE, S. Crossword puzzles: selflearning tool in pharmacology. Perspectives on Medical Education, 2012, vol. 1, n. 5-6, p. 237-248. http://dx.doi.org/10.1007/ s40037-012-0033-0. PMid:23240102.

HAMBRICK, DZ., SALTHOUSE, TA. and MEINZ, EJ. Predictors of crossword puzzle proficiency and moderators of age-cognition relations. Journal of Experimental Psychology. General, 1999, vol. 128, n. 2, p. 131-164. http://dx.doi.org/10.1037/0096-3445.128.2.131. PMid:10406103.

KARIMBUX, NY. Knowing where we're going in assessment. Journal of Dental Education, 2013, vol. 77, n. 12, p. 555. PMid:24319126.

KNÖSEL, M., JUNG, K. and BLECKMANN, A. YouTube, dentistry, and dental education. Journal of Dental Education, 2011, vol. 75, n. 12, p. 1558-1568. PMid:22184594.

KOIVUNEN, M., ANTTILA, M., KUOSMANEN, L., KATAJISTO, $J$. and VÄLIMÄKI, M. Team climate and attitudes toward information and communication technology among nurses on acute psychiatric wards. Informatics for Health \& Social Care, 2014, vol. 40, n. 1, p. 79-90. http://dx.doi.org/10.3109/17538157.2013.872112. PMid:24393065.

MCANDREW, M. and JOHNSTON, AE. The role of social media in dental education. Journal of Dental Education, 2012, vol. 76, n. 11, p. 1474-1481. PMid:23144483.

NICKERSON, RS. Five down, absquatulated: crossword puzzle clues to how the mind works. Psychonomic Bulletin \& Review, 2011, vol. 18, n. 2, p. 217-241. http://dx.doi.org/10.3758/s13423-0110069-x. PMid:21347878.

NIEDER, GL. and BORGES, NJ. An eight-year study of online lecture use in a medical gross anatomy and embryology course. Anatomical Sciences Education, 2012, vol. 5, n. 6, p. 311-320. http://dx.doi. org/10.1002/ase.1289. PMid:22674561.

OLIVEIRA, KL. and SANTOS, AAA. Avaliação da aprendizagem na univesidade. Psicologia Escolar e Educacional, 2005, vol. 9, n. 1, p. 37-46. http://dx.doi.org/10.1590/S1413-85572005000100004.
OLIVEIRA, MS., KERBAUY, MN., FERREIRA, CNM., SCHIAVÃO, LJV., ANDRADE, RFA. and SPADELLA, MA. ANDRADE, R F.A. and SPADELLA, MA. Uso de material didático sobre embriologia do sistema nervoso: avaliação dos estudantes. Revista Brasileira de Educação Médica, 2012, vol. 36, n. 1, p. 83-92. http://dx.doi. org/10.1590/S0100-55022012000100012.

PEREIRA, D.R. and FLORES, MA. Percepções dos estudantes universitários sobre a avaliação das aprendizagens: um estudo exploratório. Avaliação, 2012, vol. 17, p. 529-556.

RAINES, D. A fun way to learn terminology: the crossword puzzle. Nursing for Women's Health, 2007, vol. 11, n. 1, p. 29-31. http:// dx.doi.org/10.1111/j.1751-486X.2007.00114.x. PMid:17883813.

ROSADAS, C. "Quem sou eu? Jogo dos vírus”: uma nova ferramenta no ensino da virologia. Revista Brasileira de Educação Médica, 2012, vol. 36, n. 2, p. 264-268. http://dx.doi.org/10.1590/S010055022012000400016. [online]

ROSE, TM. A board game to assist pharmacy students in learning metabolic pathways. American Journal of Pharmacentical Education, 2011, vol. 75, n. 9, p. 1-8. http://dx.doi.org/10.5688/ajpe759183. PMid:22171111.

SAXENA, A., NESBITT, R., PAHWA, P. and MILLS, S. Crossword puzzles: active learning in undergraduate pathology and medical education. Archives of Pathology \& Laboratory Medicine, 2009, vol. 133, n. 9, p. 1457-1462. PMid:19722755.

SCOTT, KM., CHARLES, AR. and HOLLAND, AJ. Clinical embryology teaching: is it relevant anymore? ANZ Journal of Surgery, 2013, vol. 83, n. 10, p. 709-712. PMid:23678972.

SHAH, S., LYNCH, LM. and MACIAS-MORIARITY, LZ. Crossword puzzles as a tool to enhance learning about anti-ulcer agents. American Journal of Pharmacentical Education, 2010, vol. 74, n. 7, p. 117. http://dx.doi.org/10.5688/aj7407117. PMid:21088722.

SKOTKO, BG., KENSINGER, EA., LOCASCIO, JJ., EINSTEIN, G., RUBIN, DC., TUPLER, LA., KRENDL, A. and CORKIN, S. Puzzling thoughts for H. M.: can new semantic information be anchored to old semantic memories? Neuropsychology, 2004, vol. 18, n. 4, p. 756-769. http://dx.doi.org/10.1037/0894-4105.18.4.756. PMid:15506844.

SKOTKO, BG., RUBIN, DC. and TUPLER, LA. H.M.'s personal crossword puzzles: understanding memory and language. Memory, 2008, vol. 16, n. 2, p. 89-96. http://dx.doi.org/10.1080/09658210701864580. PMid:18286414.

SPEERS, AT. Crossword puzzles: a teaching strategy for critical care nursing. Dimensions of Critical Care Nursing, 1994, vol. 13, n. 1, p. 52-55. http://dx.doi.org/10.1097/00003465-199401000-00010. PMid:7882867.

TAM, CW. and EASTWOOD, A. Available, intuitive and free! Building e-learning modules using web 2.0 services. Medical Teacher, 2012, vol. 34, n. 12, p. 1078-1080. http://dx.doi.org/10.3109/014215 9X.2012.731105. PMid:23101967.

VASCONCELOS, DF. and VASCONCELOS, ACCG. Desenvolvimento de um ambiente virtual de ensino em histologia para estudantes da saúde. Revista Brasileira de Educação Médica, 2013, vol. 37, n. 1, p. 132-137. http://dx.doi.org/10.1590/S0100-55022013000100019.

Received January 8, 2015 Accepted November 17, 2015 